\title{
KARAKTER MORFOLOGIS KACANG PEDANG (Canavalia gladiata (Jacq.) DC.: FABACEAE) DAN POTENSINYA SEBAGAI PAKAN TERNAK
}

\author{
I Made Saka Wijaya ${ }^{1,3}$ dan I Wayan Suarna $2,3, *$ ) \\ 1) Program Studi Biologi, Fakultas Matematika dan IImu Pengetahuan Alam, Universitas Udayana \\ 2) Fakultas Peternakan, Universitas Udayana \\ 3) Pusat Penelitian dan Pengembangan Tumbuhan Pakan, Universitas Udayana \\ *) corresponding author: wynsuarna@unud.ac.id
}

\begin{abstract}
ABSTRAK
Indonesia memiliki berbagai jenis tumbuhan yang sangat potensial untuk dikembangkan sebagai pakan ternak, salah satunya adalah kacang pedang (Canavalia gladiata (Jacq.) DC.). Kacang pedang adalah jenis koro yang belum dimanfaatkan dengan optimal. Di Indonesia, bahkan dunia, belum banyak penelitian yang menggali potensi kacang pedang sebagai pakan ternak, padahal pengembangannya sebagai pakan ternak alternatif cukup menjanjikan. Untuk mengembangkan lebih lanjut, diperlukan kajian mengenai karakteristik morfologis dari kacang pedang untuk mencegah ambiguitas taksonomik. Maka dari itu penelitian ini bertujuan untuk mempelajari karakteristrik morfologis dari kacang pedang serta potensinya sebagai pakan ternak. Penelitan dilakukan selama bulan Mei 2019 sampai Maret 2020. Biji mulai disemai pada bulan Mei (sebagai bulan ke-1) dan dilakukan karakterisasi saat terdapat polong yang sudah matang pada bulan Maret (bulan ke-10). Fase vegetatif berlangsung selama 4-5 bulan sebelum tumbuhan mulai mengeluarkan bunga pertama. Fase generatif memiliki durasi yang bervariasi, terutama pada pematangan polong. Kematangan polong berlangsung selama 5-6 bulan, bahkan lebih. Hasil penelitian menunjukkan bahwa kacang pedang (Canavalia gladiata (Jacq.) DC.) memiliki karakteristik morfologis yang mencolok pada ukuran daun yang besar, bunga berwarna putih yang harum, polong yang berukuran besar, serta biji yang berwarna merah. Daun dan biji kacang pedang berpotensi untuk dikembangkan sebagai pakan ternak alternatif. Biji kacang pedang mengandung berbagai senyawa nutrien unggulan sebagai pakan ternak.
\end{abstract}

Kata kunci: Canavalia, karakter morfologis, pakan alternatif, pakan hijauan

\section{MORPHOLOGICAL CHARACTERISTIC OF SWORD BEAN (Canavalia gladiata (JACQ.) DC.: FABACEAE) AND ITS POTENCY AS FODDER}

\begin{abstract}
Indonesia has many tropical plants which could be developed as a forage or fodder, one of them is sword bean (Canavalia gladiata (Jacq.) DC.). Sword bean is a legume plant that distributed in tropical region and easily grow even in poor soil, but it also known as the under-utilization plant. Some researchers have done analyzed the nutrient and anti-nutrient compounds in sword bean seeds, but there is lack of research that studied the potencies of this legume plant as a fodder. To perform the further research development, it is necessary to study the morphological characteristic of this plant to avoid taxonomic ambiguity. Therefore, this study aims to know the morphological characteristics of sword bean and its potency to developed as alternative fodder. The research was carried out during May 2019 to March 2020. The seeds began to sow in May (as the $1^{\text {st }}$ month) and characterized when there were pods that were ripe in March (the $10^{\text {th }}$ month). The vegetative phase lasts for 4-5 months before the plants start flowering. The generative phase varies in duration, especially in pod maturation. Pod maturation lasts for 5-6 months, even more. The results showed that sword beans (Canavalia gladiata) had attractive morphological characteristics on large leaf sizes, fragrant white flowers, large pods, and bright red seeds. Sword bean leaves and seeds have the potential to be developed as alternative fodder. The seeds contain various superior nutrient compounds as a fodder, such as high content of protein, fiber, carbohydrate, and nitrogen free extract.
\end{abstract}

Keywords: Canavalia, fodder, sword jackbean, tropical forage 


\section{PENDAHULUAN}

Peternakan menjadi salah satu sektor yang sangat penting dalam menjaga stabilitas pangan di Indonesia. Keberhasilan dan kualitas peternakan di Indonesia ditentukan oleh berbagai faktor, seperti kualitas genetik ternak, kualitas kandang, dan pakan ternak. Ketersediaan pakan ternak menjadi sebuah isu yang sangat penting. Alih fungsi lahan telah memangkas habitat dari tanaman pakan ternak, sedangkan peternak tidak dapat hanya mengandalkan pellet atau pakan buatan saja.

Indonesia menyimpan berbagai jenis tumbuhan yang memiliki berbagai potensi, tidak terkecuali sebagai pakan ternak. Tumbuhan pakan ternak yang ideal pada saat ini adalah tumbuhan yang tidak hanya memiliki produktivitas tinggi, melainkan juga memiliki nilai estetika. Nilai estetika ini akan memperluas area penanaman pakan ternak ini. Misalkan pada rumput gajah (Pennisetum purpureum). Masyarakat tidak akan menanam rumput gajah di pekarangan rumahnya karena nilai estetikanya rendah. Masyarakat akan menanam rumput gajah tersebut di ladang atau petak sawah yang tidak difungsikan. Akibatnya ketersediaan rumput gajah menjadi tergantung terhadap eksistensi dari ladang dan petak sawah tersebut. Apabila terjadi alih fungsi pada lahan tersebut, maka rumput gajah tidak akan tersedia lagi.

Untuk mengatasi hal tersebut, maka diperlukan sebuah alternatif untuk mengembangkan tumbuhan pakan yang sekaligus memiliki nilai estetika, sehingga dapat ditanam pada areal pekarangan rumah. Salah satu yang berpotensi adalah kacang pedang atau koro pedang (Canavalia gladiata (Jacq.) DC.). Kacang pedang adalah jenis kacang koro yang banyak tersebar di Indonesia, bahkan di dunia. Saat ini, belum diketahui daerah yang menjadi asal usul dari kacang pedang ini, karena jenis yang tersebar di dunia diduga adalah jenis hibrida dan hasil budidaya. Backer \& v.d. Brink (1963) juga menyatakan bahwa kacang pedang yang dijumpai di Jawa diduga merupakan jenis yang dibudidayakan.

Kacang pedang memiliki nilai estetika yang tinggi, terutama bunga dan polongnya. Bunga kacang pedang berwarna putih dan harum, sehingga mengundang banyak serangga seperti kupu-kupu dan lebah. Polongnya yang berukuran besar seperti pedang sangat mencolok diantara daun-daunnya. Bahkan bijinya yang berwarna merah tampak lebih mencolok dari buahnya. Tumbuhan ini juga memiliki toleransi terhadap intensitas cahaya yang tinggi dan rendah (ternaungi), sehingga cocok ditanam di pekarangan atau sebagai tumbuhan pagar.

Kacang pedang termasuk tumbuhan yang kurang dimanfaatkan, meskipun memiliki berbagai potensi pemanfaatan (Ekanayake et al., 2000). Saat ini, sebagian besar penelitian mengenai kacang pedang difokuskan pada bijinya yang mengandung berbagai senyawa anti-nutrien potensial, seperti lektin, asam amino non-protein, dan polifenol (Delatorre et al., 2007). Lektin adalah protein yang memiliki interaksi spesifik dengan berbagai jenis senyawa karbohidrat, sehingga digunakan untuk mempelajari interaksi pada glikoprotein. Lektin pada kacang pedang bahkan dapat digunakan sebagai haematological marker leukemia (Nair et al., 2011). Sisi pengenal karbohidrat pada lektin juga memungkinkan lektin untuk mengenali berbagai senyawa lain, seperti asam amino nonprotein yang berperan dalam mekanisme pertahanan diri tumbuhan (Delatorre et al., 2007). Kulit bijinya yang tebal dan berwarna merah umumnya dibuang saat diolah menjadi makanan, padahal kulit biji tersebut mengandung banyak antioksidan golongan polifenol. Zhou et al. (2019) melakukan ekstraksi pada kulit biji kacang pedang dan memperoleh senyawa antioksidan alami (polifenol) yang berpotensi digunakan dalam industri nutraceutical dan makanan seperti digalloyl hexoside, methyl gallate, gallic acid, trigalloyl hexoside, and digallic acid.

Di Indonesia, bahkan dunia, belum banyak penelitian yang menggali potensi kacang pedang sebagai pakan ternak potensial, padahal pengembangan kacang pedang sebagai pakan ternak alternatif cukup menjanjikan. Untuk mengembangkan lebih lanjut, diperlukan kajian mengenai karakteristik morfologis dari kacang pedang. Karakteristik morfologis akan menjadi karakter utama untuk mengakomodasi variasi intraspesies pada kacang pedang, sekaligus menjadi ciri pembeda antar daerah. Maka dari itu penelitian ini bertujuan untuk mempelajari karakteristrik morfologis dari kacang pedang untuk mencegah ambiguitas taksonomik dalam pengembangan penelitian, serta mengetahui durasi fase vegetatifgeneratif dan potensinya sebagai pakan ternak. Ambiguitas taksonomik dapat muncul akibat asalusul dari kacang pedang yang belum jelas karena belum diketahui induk hibridanya.

\section{MATERI DAN METODE}

\section{Alat dan Bahan}

Penelitian dilakukan pada bulan Mei 2019 sampai Maret 2020. Alat dan bahan yang diperlukan adalah tray untuk mengecambahkan biji kacang pedang, media tanam (sekam kering: tanah biasa : tanah subur : pupuk kandang dengan perbandingan 1:2:1:1:1), biji kacang pedang yang diperoleh di Kecamatan Ubud, polybag ukuran $15 \times 15 \mathrm{~cm}$ dan $40 \times 40 \mathrm{~cm}$, dan peralatan dokumentasi yang terdiri dari kamera digital, penggaris, layer background, dan alat tulis. 


\section{Cara Kerja dan Analisis Data}

Persemaian kacang pedang dilakukan di greenhouse dengan cara mengecambahkan 10 biji dalam tray. Setelah 7 hari, semai dipindahkan ke dalam polybag ukuran $15 \times 15 \mathrm{~cm}$ yang telah diberi media tanam sebanyak 3/4 volume polybag. Pada hari ke-14, semai dipindahkan pada polybag ukuran $40 \times \times 40 \mathrm{~cm}$. Setelah 28 hari, semai pada polybag dipindahkan ke lahan terbuka (tinggi tanaman sekitar 1,5 m). Pengamatan dilakukan sampai terdapat buah yang matang, sehingga diperoleh kisaran durasi vegetatif dan generatif (dari munculnya bunga sampai matangnya buah). Saat bagian vegetatif dan generatif sudah lengkap, maka dilakukan karakterisasi morfologis yang terdiri dari habitus, batang, daun, bunga, buah/polong, dan biji berdasarkan Rugayah et al. (2004). Data yang diperoleh dianalisis secara deskriptif untuk mengetahui karakteristik morfologis kacang pedang.

\section{HASIL DAN PEMBAHASAN}

\section{Klasifikasi dan Karakter Morfologis Kacang Pedang (Canavalia gladiata (Jacq.) DC.)}

Kacang pedang merupakan tumbuhan polongpolongan yang banyak terdistribusi di daerah tropis, namun belum diketahui asal usulnya karena jenis yang ditanam kemungkinan adalah jenis yang telah dibudidayakan. Hal ini menyebabkan ambiguitas taksonomik intraspesies berdasarkan karakter morfologis. Klasifikasi spesies kacang pedang adalah sebagai berikut:

$\begin{array}{ll}\text { Kingdom } & \text { : Plantae } \\ \text { Division } & \text { : Magnoliophyta } \\ \text { Class } & \text { : Magnoliopsida } \\ \text { Order } & \text { : Fabales } \\ \text { Family } & \text { : Fabaceae } \\ \text { Subfamily } & \text { : Papilionideae } \\ \text { Genus } & \text { : Canavalia } \\ \text { Species } & \text { : Canavalia gladiata (Jacq.) DC. }\end{array}$

Synonyms : (derived from http://www. theplantlist.org/tpl/record/ild-3630) Canavalia ensiformis var. alba Makino; C. ensiformis var. gladiata (Jacq.) Kuntze; Canavalia foureiri G. Don; C. gladiolata J. D. Sauer; C. incurva (Thunb.) DC.; C. incurva Thouars; C. loureirii G. Don; $C$. machaeroides (DC.) Steud.; $C$. maxima Thouars; Dolichos gladiatus Jacq.; D. incurvus Thunb.; Malocchia gladiata (Jacq.) Savi

Common names: sword jackbean, sword bean, red ssword bean (English); kacang pedang, koro pedang (Indonesia); kacang parang (Malaysia)
Di Indonesia, kacang pedang dapat dijumpai di berbagai daerah, terutama di Jawa melalui catatan dari Backer \& v.d. Brink (1963). Secara umum, karakteristik morfologis kacang pedang di Bali dengan Jawa tidak berbeda secara kualitatif. Kacang pedang memiliki habitus berupa tumbuhan merambat perennial dengan pertumbuhan batang sekitar 3-10 m. Karakteristik daun kacang pedang (Gb. 1a-b) berupa daun majemuk beranak daun 3 (trifoliate), bagian adaksial berwarna hijau dan bagian abaksial berwarna hijau pucat, helaian berbentuk bulat teluroval, berukuran 11,2-17,5 $\times$ 9,1-12,8 $\mathrm{cm}$, tepi ratabergelombang, ujung runcing-meruncing pendek, pangkal daun runcing, panjang tangkai daun $0,7-1$ $\mathrm{cm}$, panjang ibu tangkai daun $9,5-20,2 \mathrm{~cm}$, memiliki sayap di bagian ventral.

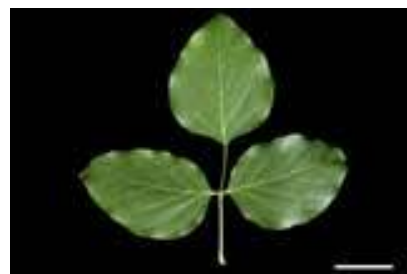

(a)

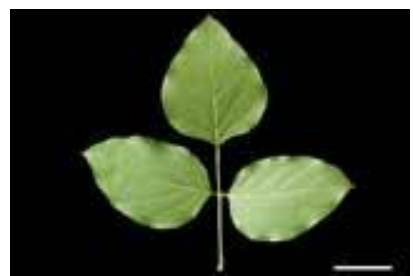

(b)
Gambar 1. Karakteristik daun kacang pedang (a). Daun bagian adaksial dan (b) daun bagian abaksial.

Bar: $5 \mathrm{~cm}$

Kacang pedang memiliki pembungaan majemuk, tandan, tangkai pembungaan menjuntai, terdapat 4-20 kuntum bunga yang mekar dari pangkal (tak berbatas), kuntum bunga tersusun tersebar dan sangat mudah rontok (Gb. 2a). Karakteristik umum perhiasan bunga ditunjukkan oleh Gb. 2b, sedangkan section perhiasan bunga ditunjukkan pada Gb. 2c. Kelopak bunga berwarna hijau, synsepalum, membentuk tabung berukuran 0,8-1,2 × 0,6-0,7 cm, dua sepala ventral berukuran lebih panjang dan melekuk ke bawah, dua sepala lateral berukuran lebih pendek dan mengapit satu sepala dorsal yang berbentuk tombak dengan ujung runcing. Mahkota bunga berwarna putih, beraroma harum tipis, daun mahkota terdiferensiasi menjadi dua lunas (carina), dua sayap (alae), dan satu bendera (vexillum). Lunas terletak paling dalam dengan bagian dorsal yang saling melekat, berbentuk sabit, berukuran 3,5 × 1-1,2 $\mathrm{cm}$, tepi rata, ujung tumpul. Sayap mengapit lunas di bagian kanan dan kiri, berbentuk sabit, berukuran 3,2-3,5 $\times 0,6-0,7 \mathrm{~cm}$, tepi rata namun berlekuk, ujung tumpul. Bendera terdiri dari dua bagian, yaitu bagian kaki yang berukuran 1-1,1 $\times 1 \mathrm{~cm}$ dan memiliki taji, dan bagian bendera yang melekuk ke bawah, berbentuk segilima, berukuan $2,5 \times 2,5 \mathrm{~cm}$, tepi rata namun melekuk ke bawah, bagian ujung rata-terbelah dan juga melekuk ke bawah sehingga bendera tampak berbentuk persegi. Putik melengkung, berwarna 
putih, memiliki panjang $3,2-3,5 \mathrm{~cm}$, kepala putik membulat. Benang sari berjumlah 10, monodelphous, kepala sari berwarna kuning kecokelatan, berbentuk oval, berukuran $0,2-0,15 \mathrm{~cm}$.

Pada saat mekar, bunga kacang pedang menarik berbagai jenis serangga seperti lebah, tawon, dan berbagai jenis semut. Kehadiran serangga tersebut berpotensi sebagai polinator bunga kacang pedang. Hal ini sangat penting, sebab bunga kacang pedang sangat mudah rontok, sehingga polinasi harus terjadi sebelum bunga rontok.

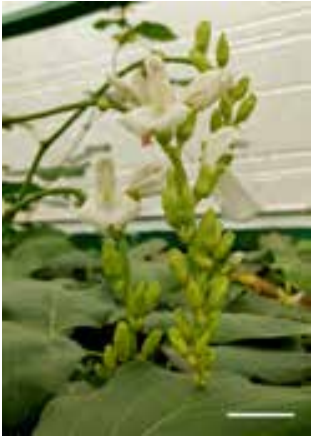

(a)

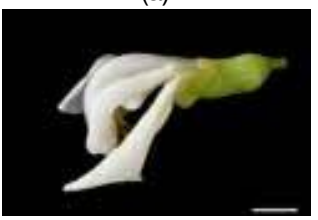

(b)

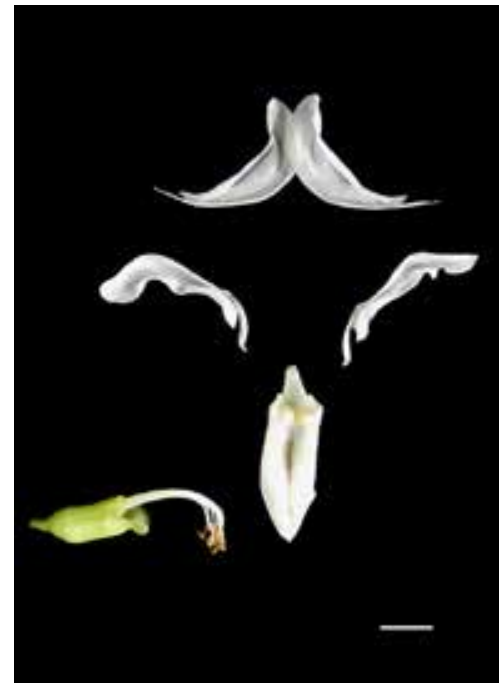

(c)
Gambar 2. Karakter pembungaan dan bunga kacang pedang (a). Pembungaan tandan; (b). Kuntum bunga; dan (c). Bagian perhiasan bunga

Bar: $a=2 \mathrm{~cm} ; b-c=1 \mathrm{~cm}$

Buah berupa polong yang berukuran besar, berwarna hijau kekuningan saat muda dan kecokelatan saat dewasa/matang, berbentuk silindris pipih, berukuran $32 \times 4 \mathrm{~cm}$ dengan tebal 2.5-3 cm (Gb. 3a). Biji berwarna merah muda-merah cerah, berbentuk oval, berukuran $3 \times 2 \mathrm{~cm}$, tebal biji $1.3 \mathrm{~cm}$, hilum terlihat jelas, berbentuk silindris dengan panjang 2,4 cm (Gb. 3b). Biji yang masih muda memiliki permukaan kulit yang mengkilap (Gb. 3c), namun perlahan-lahan akan menjadi kisut dan semakin gelap. Pada biji yang sudah matang ( $\mathrm{Gb} 3 \mathrm{~d}$ ), permukaan kulit tidak mengkilap dan berwarna merah yang merata, serta meninggalkan bekas hilum berwarna hitam.

Durasi fase vegetatif dan generatif dari kacang pedang ditunjukkan pada Tabel 1. Kacang pedang mulai berkecambah pada hari ke-3 sampai ke-5, kemudian tumbuh merambat dengan cepat. Pada minggu ke-2, tumbuhan dipindahkan ke dalam polybag yang lebih besar (ukuran $40 \times 40 \mathrm{~cm}$ ). Pada minggu ke-4 (akhir bulan ke-1), tumbuhan dipindahkan ke lahan terbuka untuk optimalisasi pertumbuhan dan perkembangannya.

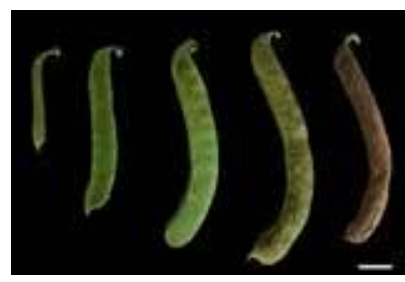

(a)

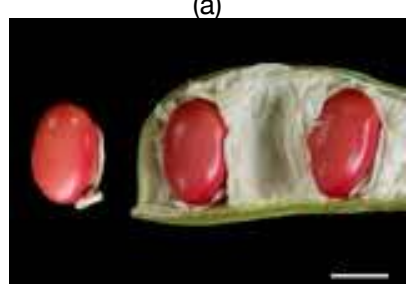

(c)

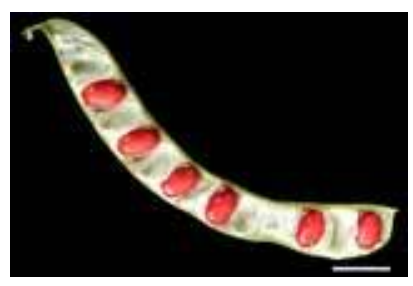

(b)

(d)

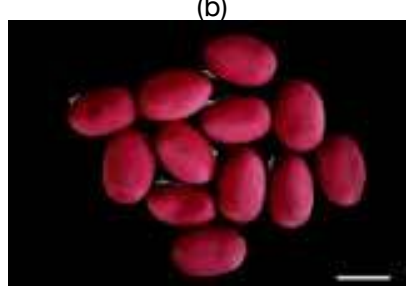

Gambar 3. Polong dan biji kacang pedang (a). Perbandingan perkembangan polong dari termuda sampai matang; (b). Posisi biji pada polong; (c). Plasentasi biji pada polong; dan (d). Biji yang sudah matang.

Bar: $a-b=5 \mathrm{~cm} ; c-d=2 \mathrm{~cm}$

Tabel 1. Durasi Fase Vegetatif dan Generatif pada Kacang Pedang

\begin{tabular}{|c|c|c|c|c|c|c|c|c|c|c|c|}
\hline \multirow{2}{*}{ No } & \multirow{2}{*}{ Fase } & \multicolumn{10}{|c|}{ Durasi (Bulan ke-) } \\
\hline & & 1 & 2 & 3 & 4 & 5 & 6 & 7 & & & 10 \\
\hline 1 & V: Perkecambahan & & & & & & & & & & \\
\hline 2 & $\begin{array}{l}\text { V: Pertumbuhan } \\
\text { batang \& daun }\end{array}$ & & & & & & & & & & \\
\hline 3 & G: Pembungaan & & & & & & & & & & \\
\hline 4 & G: Pembentukan buah & & & & & & & & & & \\
\hline 5 & G: Pematangan buah & & & & & & & & & & \\
\hline
\end{tabular}

$\mathrm{V}$ : fase vegetatif

G: fase generatif

Fase vegetatif berlangsung sekitar 4-5 bulan sebelum tumbuhan menghasilkan tandan bunga pertamanya. Pada fase tersebut, tumbuhan sudah melilit tinggi sampai ketinggian $4 \mathrm{~m}$. Saat tandan bunga pertama muncul, kuntum bunga hanya bertahan sekitar 3 hari, sebelum akhirnya rontok pada bagian tangkai bunganya. Bunga tidak akan rontok apabila sudah terjadi pembuahan. Pada tahap awal pembuahan, mahkota bunga akan mulai seiring dengan pertumbuhan polong, sampai akhirnya hanya tersisa polong saja tanpa perhiasan bunga. Pertumbuhan polong juga diikuti dengan pertumbuhan tangkai bunga dan tangkai pembungaan yang semakin besar dan kuat.

Pada proses pematangan buah, terdapat perubahan warna sebagai berikut: hijau cerah, hijau pucat, hijau kekuningan, hijau kecokelatan, cokelat, cokelat kehitaman. Dilihat dari tekstur kulit dan daging polong yang tebal dan ukuran buah yang besar, pematangan buah kacang pedang berlangsung dalam 5-6 bulan sejak terjadinya pembuahan. Saat terjadi proses generatif (pembungaan sampai pembuahan), proses vegetatif tetap berlangsung. Saat buah yang 
Tabel 2. Kandungan Senyawa Nutrien pada Biji Kacang Pedang

\begin{tabular}{|c|c|c|c|c|c|c|}
\hline \multirow{2}{*}{ No } & \multirow{2}{*}{ Nutrien } & \multicolumn{5}{|c|}{ Kandungan dalam biji (g/10o g) } \\
\hline & & ST & MT-a & MT-b & EK & VJ \\
\hline 1 & Protein & $29 \%$ & $27,87 \%$ & $28,9 \%$ & $29,2 \%$ & $25,5 \%$ \\
\hline 2 & Serat & $6 \%$ & $4,07 \%$ & $3,47 \%$ & $10,2 \%$ & $5,9 \%$ \\
\hline 3 & Karbohidrat & $37 \%$ & (NE) & $(\mathrm{NE})$ & $53,2 \%$ & $61,8 \%$ \\
\hline 4 & NFE & $62 \%$ & $54,01 \%$ & $55,21 \%$ & $(\mathrm{NE})$ & $(\mathrm{NE})$ \\
\hline 5 & Lemak & $1,6 \%$ & $9,9 \%$ & $9,23 \%$ & $3,1 \%$ & $3,3 \%$ \\
\hline 6 & Gula larut & $7,5 \%$ & $(\mathrm{NE})$ & $(\mathrm{NE})$ & $(\mathrm{NE})$ & (NE) \\
\hline 7 & $\mathrm{Abu}$ & $(\mathrm{NE})$ & $4,15 \%$ & $3,19 \%$ & $4,3 \%$ & $3,5 \%$ \\
\hline
\end{tabular}

NE: Not evaluated

NFE: Nitrogen Free Extractive

ST: biji dari Brazil (Spaldore \& Teixeira, 1987)

MT-a: biji dari Kalakad Wildlife Sanctuary, India (Mohan \& Janardhanan 1994)

MT-b: biji dari Mundanthurai Wildlife Sanctuary, India (Mohan \& Janardhanan 1994)

EK: biji dari Sri Lanka (Ekanayake et al., 1999)

VJ: biji dari India Selatan (Vavidel \& Janardhanan, 2005)

pertama sudah matang, tinggi tumbuhan mencapai 5-6 m dan hampir menutupi kanopi dari pohon yang dirambati.

\section{Potensi Kacang Pedang (Canavalia gladiata (Jacq.) DC.) sebagai Pakan Ternak}

Kacang pedang tumbuh dengan baik di daerah tropis dan memiliki karakter agronomi yang potensial untuk dikembangkan sebagai pakan ternak, terutama daun dan bijinya. Daun kacang pedang yang berukuran besar dapat dimanfaatkan sebagai pakan ternak, sama halnya seperti daun pada tumbuhan polong-polongan lainnya. Namun, analisis proksimat pada daun kacang pedang perlu dilakukan untuk mengetahui kandungan nutriennya secara pasti. Potensi tersebut juga hampir sama dengan kerandang (Canavalia virosa) sebagai sumber pakan pada lahan salin sebagaimana penelitian yang dilakukan oleh Sajimin dan Prawiradiputra (2014).

Berbeda dengan daun kacang pedang, kandungan nutrien pada biji kacang pedang sudah banyak dikaji. Biji kacang pedang mengandung berbagai senyawa nutrien dan anti-nutrien. Analisis kandungan senyawa nutrien utama pada biji kacang pedang ditunjukkan oleh Tabel 2. Kandungan protein pada biji kacang pedang termasuk tinggi dengan rentang 25,5-29,2\%. Kandungan protein tersebut sama seperti kandungan protein kacang pada umumnya (Bressani et al., 1987), sehingga sangat potensial untuk dikembangkan sebagai pakan ternak unggulan. Cadangan protein utama pada biji kacang pedang berupa senyawa khas yang disebut canavalin (Nishizawa dan Arii, 2018).

Kandungan serat, karbohidrat, dan lemak pada biji kacang pedang sangat bervariasi. Kandungan serat berkisar pada 3,47-10,2\%, karbohidrat sangat bervariasi dari $37-61,8 \%$, serta lemak berkisar pada 1,6 - 9,9\%. Karbohidrat dibagi menjadi dua golongan yaitu serat kasar dan bahan ekstrak tanpa nitrogen (BETN) atau nitrogen free extractive (NFE). Serat kasar adalah bagian struktur sel pada jarinan tanaman. Serat kasar mengandung selulosa, hemiselulosa, polisakarida dan lignin. Kandungan NFE pada kacang pedang sangat tinggi yakni 54,61 $-62 \%$. Bahan ekstrak tanpa nitrogen (BETN) adalah sekelompok karbohidrat yang kecernaannya tinggi, sedangkan dalam analisis proksimat yang dimaksud NFE adalah komponen karbohidrat yang mudah dicerna dan sebagai sumber energi yang baik bagi ternak. Nilai BETN didapatkan dari 100\% bahan dikurangi persentase abu, serat kasar, lemak dan protein kasar. Kandungan BETN yang tinggi pada koro pedang sangat potensial sebagai sumber energi pada ternak non ruminansia serta karbohidrat mudah tercerna ini juga sangat potensial dalam pengembangan ternak ruminansia terutama pada sistem feedlot.

Biji kacang pedang juga dikenal karena memiliki berbagai senyawa anti-nutrien yang dapat bersifat toksik bagi tubuh manusia, sehingga jarang dimanfaatkan sebagai makanan (Spaldore dan Teixeira, 1987) karena memerlukan berbagai tahap pengolahan dengan durasi 5-6 hari (Ekanayake et al., 1999). Senyawa anti-nutrien pada biji kacang pedang dapat berupa lektin, asam amino non-protein, maupun metabolit sekunder seperti antioksidan. Asam amino non-protein adalah senyawa yang umum dijumpai pada biji tumbuhan polong-polongan, dengan kuantitas mencapai 10\% dari berat kering biji (Delatorre et al., 2007). Asam amino non-protein sangat penting bagi tumbuhan polong-polongan karena berperan sebagai cadangan nitrogen (Rosenthal, 1991) dan pertahanan terhadap patogen. Salah satu contohnya adalah Aminobutyric acid yang berperan dalam mekanisme pertahanan terhadap patogen melalui interaksinya dengan lektin yang juga terdapat pada biji kacang pedang (Delatorre et al., 2007). 


\section{SIMPULAN}

Kacang pedang (Canavalia gladiata (Jacq.) DC.) memiliki karakteristik morfologis yang mencolok pada ukuran daun yang besar, bunga berwarna putih yang harum, buah yang berukuran besar, serta biji yang berwarna merah. Daun dan biji kacang pedang berpotensi untuk dikembangkan sebagai pakan ternak alternatif. Biji kacang pedang mengandung berbagai senyawa nutrien unggulan sebagai pakan ternak.

\section{DAFTAR PUSTAKA}

Backer, C.A. and R.C.B. van den Brink. 1963. Flora of Java (Spermatophyte only) vol. I. The Rijksherbarium: Leyden. Pp. 622-623.

Bressani, R., B.R. Gomez, A. Garcia, and L.G. Eliaz. 1987. Chemical composition, amino acid content and protein quality of Canavalia seeds. $J$. Sci Food Agric 40: 17-23.

Delatorre, P., B.A.M. Rocha, E.P. Souza, T.M. Oliveira, G.A. Bezerra, F.B.M.B. Moreno, B.T. Freitas, T. Santi-Gadelha, A.H. Sampaio, W.F. Azevedo Jr, and B.S. Cavada. 2007. Structure of a lectin from Canavalia gladiata seeds: new structural insights for old molecules. BMS Structural Biology 7(52): 1-9 doi: 10.1186/1472-6807-7-52.

Ekanayake, S., E.R. Jansz, and B.M. Nair. 1999. Proximate composition, mineral and amino acid content of mature Canavalia gladiata seeds. Food Chemistry 66: 115-119.

Ekanayake, S., E.R. Jansz, and B.M. Nair. 2000. Literature review of an underutilized legume: Canavalia gladiata L. Plant Foods Hum Nutr 55: 305-321.

Mohan, V.R. and K. Janardhanan. 1994. The biochemical composition and nutrient assessment of less known pulses of the genus Canavalia. International Journal of Food Sciences and Nutrition 45: 255-262.
Nair, L.S., S. Mahesh, L.S. Smitha, K. Sujathan, P. Remani. 2011. Expression of Canavalia gladiata lectin in leukemic cells. J. Cancer Sci Ther 3: 8891 doi: 10.4172/1948-5956.1000066.

Nishizawa, K. and Y. Arii. 2018. Sword bean variants and different pretreatments influence protein extraction and protein properties. Bioscience, Biotechnology, and Biochemistry 82(10): 18211824 doi: 10.1080/09168451.2018.1487273.

Rosenthal, G.A. 1991. The biochemical basis for the deleterious effects of L-canavanine. Phytochemistry 30: 1055-1058.

Rugayah, A. Retnowati, F.I. Windadri, and A. Hidayat. 2004. Pengumpulan data taksonomik. In "Pedoman pengumpulan data keanekaragaman flora” ed. Rugayah, E.A. Widjaja, and Praptiwi. Pusat Penelitian Biologi LIPI: Indonesia. Pp. 5-42.

Sajimin dan B.R. Prawiradiputra. 2014. Evaluasi Produktivitas Tanaman Kerandang (Canavalia Virosa) Sebagai Sumber Hijauan Pakan Ternak Pada Lahan Pantai. Pastura 3(2): 75-78.

Spoladore, D.S. and J.P.F. Teixeira. 1987. Chemical composition of seeds of Canavalia gladiata DC. Bragantia 48(1): 133-139.

The Plant List. http://www.theplantlist.org/tpl/ record/ild-3630 (diakses tanggal 20 Maret 2020).

Vadivel, V. and K. Janardhanan. 2005. Nutrition and antinutritional characteristics of seven South India legumes. Plant Foods Hum Nutr. 60: 69-75.

Zhou, Y., X. Xu, R. Gan, J. Zheng, Y. Li, J. Zhang, D. $\mathrm{Xu}$, and H. Li. 2019. Optimization of ultrasoundassisted extraction of antioxidant polyphenols from the seed coats of red sword bean (Canavalia gladiata (Jacq.) DC.). Antioxidants 8(200) doi: 10.3390/antiox8070200. 